$4^{\text {th }}$ International Meeting on Calcitonin Gene-Related Peptide (CGRP)

TheScientificWorld (2001) 1(S1), 8

ISSN 1532-2246; DOI 10.1100/tsw.2001.405

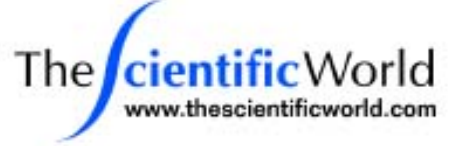

\title{
STRUCTURAL DETERMINANTS IN THE CALCITONIN RECEPTOR-LIKE RECEPTOR (CRLR) IMPORTANT FOR CGRP AND ADRENOMEDULLIN (AM) RECEPTOR FUNCTION OF CRLR/RECEPTOR-ACTIVITY-MODIFYING PROTEIN (RAMP) 1 AND CRLR/RAMP2 HETERODIMERS
}

\author{
W. Born, K. Leuthäuser, R. Gujer, R. Muff, and J.A. Fischer \\ Research Laboratory for Calcium Metabolism, University of Zurich, Klinik Balgrist, 8008 Zurich, \\ Switzerland
}

Cell surface protein cross-linking, coimmmunoprecipitation, and confocal microscopy identified CRLR/RAMP1-, CRLR/RAMP2-, and calcitonin receptor isotype 2 (CTR2)/RAMP1 heterodimers as CGRP-, AM-, and CGRP/amylin receptors, linked to cAMP production. Along these lines, effects of structural alterations in the N-terminal extracellular domain of the human CRLR on cell surface expression as well as the association with RAMP and CGRP or AM have been investigated.

Site-directed mutagenesis identified $\mathrm{Asn}^{60}$ and $\mathrm{Asn}^{112}$ as N-glycosylation sites. Nglycosylation was important for cell surface expression of CRLR/RAMP complexes, but not for ligand specificity. Substitution of $\mathrm{Asn}^{117}$ by Asp, on the other hand, maintained normal CRLR function and N-glycosylation, but $\mathrm{Asn}^{117}$ to Thr, Ala, Gln, or Pro mutations revealed inactive mutant CRLR/RAMP1 heterodimers at the cell surface.

Substitution of the N-terminal 18 amino acids of the CRLR by the corresponding CTR2 domain did not affect RAMP1-dependent CGRP receptor function, but RAMP2-mediated AM binding was abolished and the $\mathrm{EC}_{50}$ of AM stimulating cAMP accumulation was raised over 100fold.

In conclusion, differential interactions of CGRP and AM have been identified in the Nterminal extracellular region (1-118) of the human CRLR. 

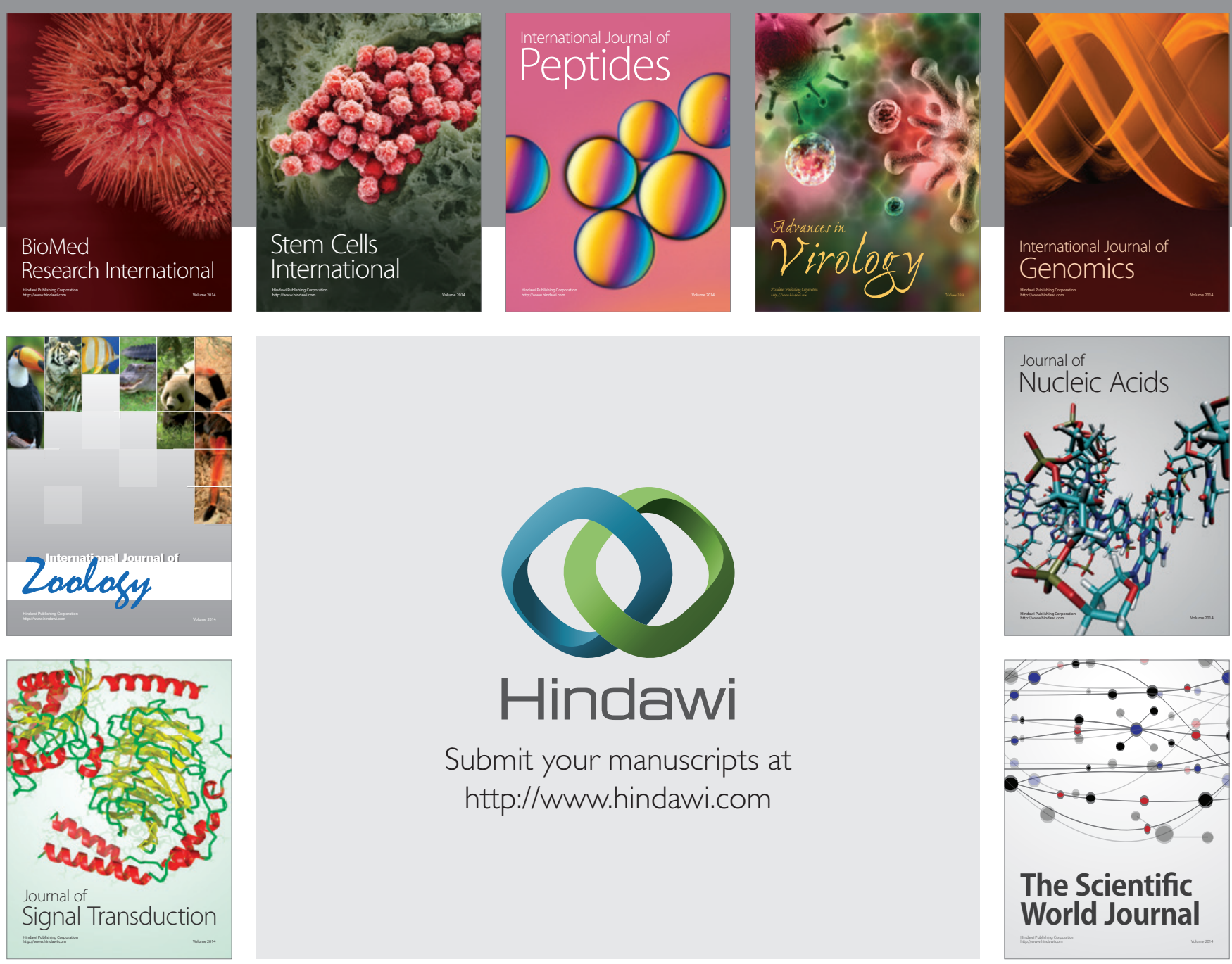

Submit your manuscripts at

http://www.hindawi.com
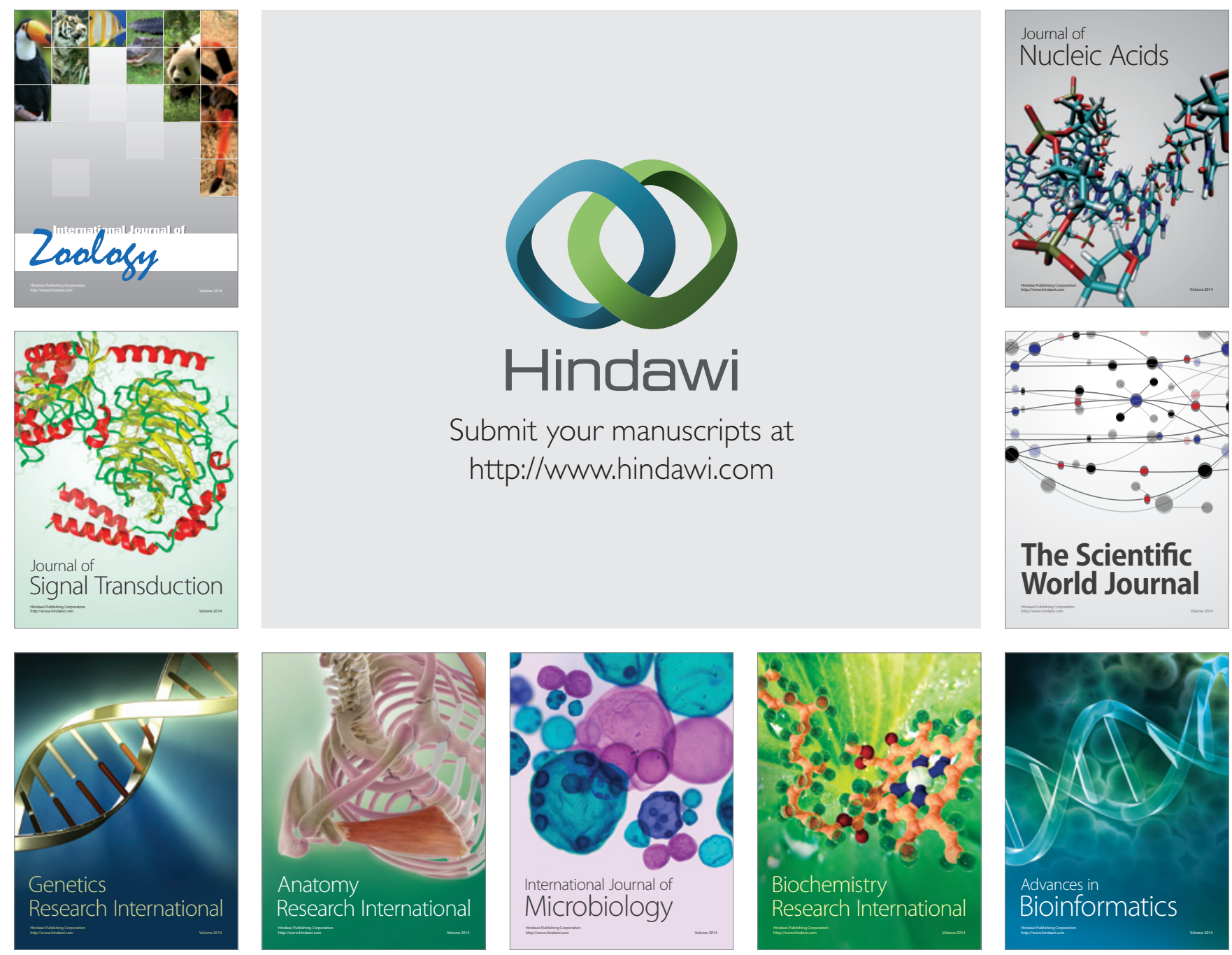

The Scientific World Journal
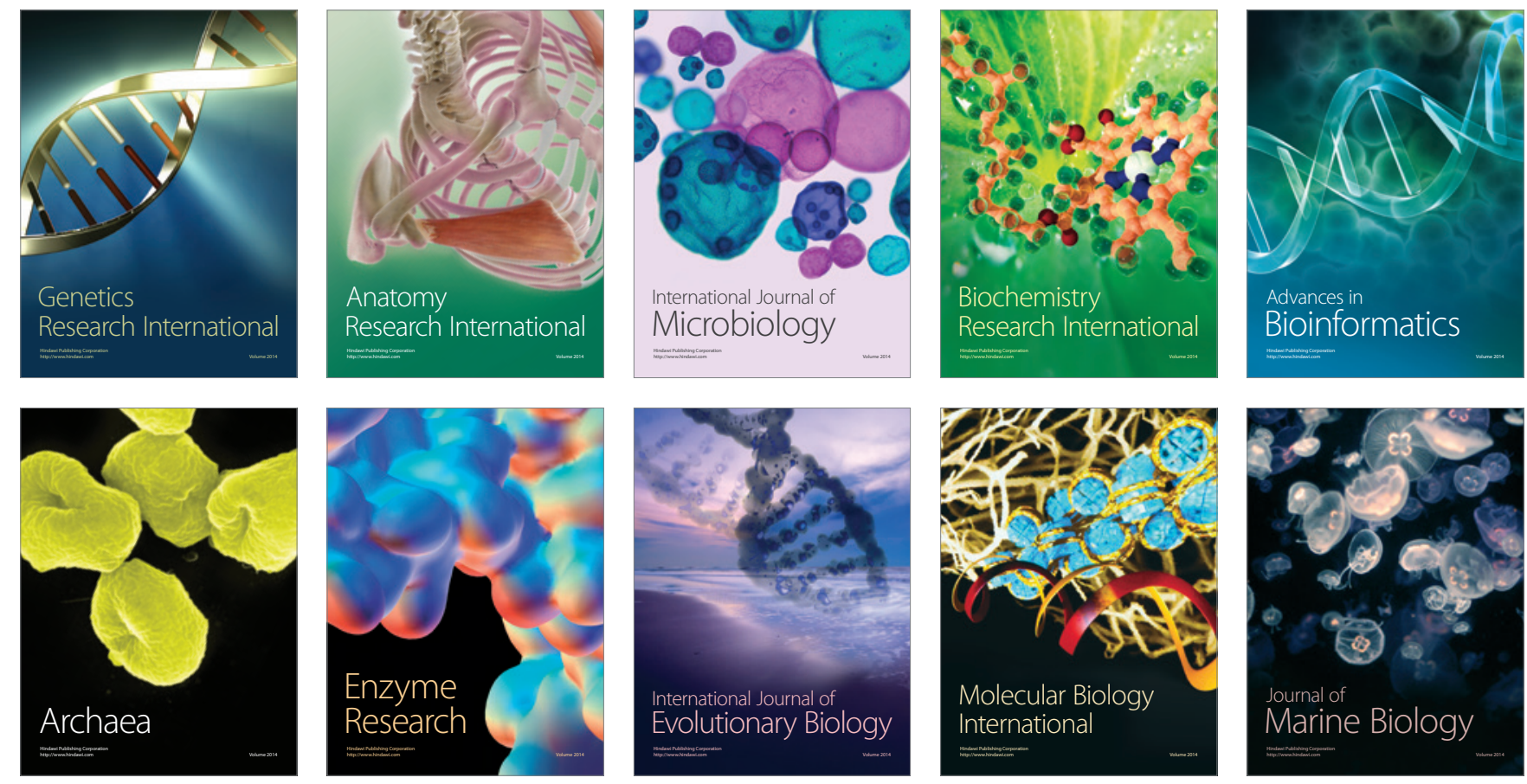